\title{
Janusz Tomaszewski
}

ORCID: 0000-0002-4638-4818

Uniwersytet Wrocławski

\section{Odrodzenie Wojska Polskiego 1918-1921}

DOI: $10.19195 / 1643-0328.27 .13$

Słowa kluczowe: Wojsko Polskie, niepodległość, formowanie, front, pobór, scalenie, służba, walka

\section{Wprowadzenie}

11 listopada 1918 roku po 123 latach niewoli Rzeczpospolita ponownie wybiła się na niepodległość. Dokonało się to nie tylko w wyniku klęski militarnej wszystkich trzech jej zaborców w pierwszej wojnie światowej, lecz także dzięki ogromnej determinacji, walce i poświęceniu całych pokoleń Polaków pragnących żyć we własnej, wolnej ojczyźnie.

$\mathrm{W}$ odbudowywanych strukturach państwa polskiego ważne miejsce zajmowała armia. Miała ona, niezależnie od decyzji zwycięskich mocarstw podejmowanych w kwestii polskiej na konferencji pokojowej w Paryżu, wywalczyć stabilne i bezpieczne granice dla Rzeczypospolitej, stać na straży jej niepodległego i suwerennego bytu oraz wspomagać jej niezakłócony rozwój wewnętrzny.

\section{Początki formowania}

Jest rzeczą znamienną, że Wojsko Polskie zaczęło się organizować jeszcze przed formalnym wskrzeszeniem państwa polskiego. W październiku i na początku listopada 1918 roku formowało się ono na podstawie trzech ośrodków decyzyjnych - Rady Regencyjnej Królestwa Polskiego, Polskiej Komisji Likwidacyjnej (PKL) i Tymczasowego Rządu Ludowego Republiki Polskiej.

Proces tworzenia Wojska Polskiego (dalej: WP) zapoczątkowała, powstała we wrześniu 1917 roku z woli Niemiec i Austro-Węgier w miejsce rozwiązanej Tymczasowej Rady Stanu, Rada Regencyjna Królestwa Polskiego ${ }^{1}$. Przede wszystkim opracowała ona

${ }^{1}$ Powołano ją 12 września 1917 roku w Warszawie jako formalnie najwyższą władzę tymczasową w Królestwie Polskim. W jej składzie znaleźli się: arcybiskup warszawski Aleksander Kakowski, książę Zdzisław Lubomirski i Józef Ostrowski, na czele rządu Rady Regencyjnej KP stanął zaś Jan Kucharski. 
wiele dokumentów stanowiących podstawę rozwoju armii polskiej już w wolnej Rzeczypospolitej. Pod patronatem Rady Regencyjnej KP, aczkolwiek początkowo za niemiecką zgodą i z niemieckim dowództwem naczelnym, formowano polskie pododdziały i oddziały wojskowe, które pod nazwą Polskiej Siły Zbrojnej stanowiły namiastkę odrodzonego Wojska Polskiego ${ }^{2}$.

To w tej formacji, nazywanej również polskim „Wehrmachtem”, między innymi przystosowano lub opracowano kilkadziesiąt regulaminów wojskowych, które obowiązywały w armii polskiej do 1921 roku. W tym celu stworzono też niemal od nowa polskie słownictwo wojskowe ${ }^{3}$. Oprócz tego, jak pisał Jan Rzepecki,

Polska Siła Zbrojna dała jednolicie wyszkoloną kadrę instruktorską, która stała się cementem, spajającym w ciągu kilku miesięcy w jedną całość legionistów, peowiaków, żołnierzy wojska wielkopolskiego, hallerczyków, dowborczyków i żołnierzy wojska austriackiego. „Wehrmachtowcy” długo jeszcze potem pracowali na większości kierowniczych stanowisk w szkolnictwie wojskowym i w tych komórkach sztabów, które kierowały wyszkoleniem i pracą nad nowymi regulaminami ${ }^{4}$.

W październiku 1918 roku Rada Regencyjna, przewidując nieuchronną i rychłą klęskę państw centralnych w toczącej się wojnie, podjęła działania zmierzające do uwolnienia się spod zależności niemieckiej, przejęcia administracji od władz okupacyjnych i roli ośrodka kierowniczego w odbudowującym się państwie. Kroki te były też obliczone na pozyskanie dla Rady poparcia szerszych kręgów społeczeństwa polskiego, które zasadniczo nie darzyło jej zaufaniem.

Dnia 7 października 1918 roku skierowała ona manifest do narodu polskiego, w którym, powołując się na trzynasty punkt orędzia prezydenta USA Woodrowa Wilsona, zawarła postulat utworzenia niepodległego państwa polskiego $\mathrm{z}$ dostępem do morza ${ }^{5}$. Był to praktycznie pierwszy akt władzy polskiej proklamujący zjednoczenie wszystkich ziem przedrozbiorowych i odbudowę państwowości polskiej.

Dnia 12 października 1918 roku ukazał się dekret Rady Regencyjnej o wprowadzeniu tekstu nowej roty przysięgi wojskowej i objęciu przez nią zwierzchniej władzy nad Polską Siłą Zbrojną ${ }^{6}$. Z kolei 27 października 1918 roku ogłosiła ona formowanie „narodowej armii regularnej" na podstawie tymczasowej ustawy o powszechnym obowiązku służby wojskowej. Zwróciła się też z apelem do wszystkich oficerów i żołnierzy, którzy służyli w Legionach Polskich lub innych formacjach wojskowych, aby zgłaszali się do szeregów odradzającego się Wojska Polskiego ${ }^{7}$.

Jednocześnie z inicjatywy działającej w ramach Rady Regencyjnej Komisji Wojskowej przystąpiono do organizowania zrębów naczelnych władz wojskowych. Dnia 25 października 1918 roku na mocy dekretu Rady Regencyjnej utworzono Sztab Generalny

${ }^{2}$ Na czele Polskiej Siły Zbrojnej stał niemiecki generał-gubernator warszawski, gen. płk Hans Hartwig von Beseler. Inspektoratem Wyszkolenia kierował gen. por. Feliks von Barth. Pozostałe stanowiska dowódcze zajmowali polscy oficerowie. Por. Odrodzenie Wojska Polskiego 1918-1921 w materiałach Centralnego Archiwum Wojskowego, Warszawa 2008, s. 118-122.

3 Ibidem, s. 122.

4 Cyt. za: ibidem, s. 124.

5 Ibidem, s. 139.

${ }^{6}$ Ibidem.

7 Ibidem, s. 139, 149-150. 
Wojsk Polskich, którego szefem trzy dni później mianowano awansowanego na stopień gen. dyw. Tadeusza Jordan-Rozwadowskiego. Sztab Generalny WP miał się składać z siedmiu wydziałów, a jego podstawowym zadaniem w najbliższych miesiącach było formowanie Wojska Polskiego i organizowanie terenowej administracji wojskowej ${ }^{8}$.

Dnia 26 października 1918 roku podjęto decyzję o przekształceniu Komisji Wojskowej w Ministerstwo Spraw Wojskowych z Józefem Piłsudskim jako kierownikiem. Na czas jego nieobecności resortem miał zarządzać płk Jan Wroczyński ${ }^{9}$.

Rozporządzeniem Prezydenta Rady Ministrów Józefa Świeżyńskiego z 30 października 1918 roku obszar Królestwa Polskiego pod okupacją austriacką i niemiecką został podzielony na piętnaście okręgów wojskowych. Każdy z nich obejmował kilka powiatów i powinien był wystawić batalion, później pułk, a w końcu dwupułkową brygadę piechoty, uzupełnianych w razie potrzeby rekrutami z danego okręgu. Na początku listopada 1918 roku okręgi wojskowe zostały podporządkowane trzem inspektoratom, których siedziby znajdowały się w Warszawie, Kielcach i Lublinie. Miały one sprawować ogólny nadzór nad działalnością wojskowo-organizacyjną okręgów ${ }^{10}$.

W tym czasie proces formowania Wojska Polskiego, które praktycznie ograniczało się do reorganizowanej Polskiej Siły Zbrojnej, powoli postępował. Wynikało to przede wszystkim, o czym już wspomniano, z nikłego poparcia społeczeństwa polskiego dla poczynań Rady Regencyjnej patronującej odradzaniu się armii polskiej. Innym powodem był niechętny stosunek niemieckich władz wojskowych okupujących Królestwo Polskie, zwłaszcza generała-gubernatora warszawskiego gen. Hansa Hartwiga von Beselera, który jednocześnie do 20 października 1918 roku formalnie dowodził Polską Siłą Zbrojną ${ }^{11}$.

W pierwszej kolejności organizowano formacje piechoty i kawalerii. Opieranie się na zaciągu ochotniczym utrudniało tworzenie większych jednostek i związków taktycznych. Dlatego formowano głównie pododdziały: bataliony, szwadrony, baterie, kompanie, łącząc je następnie w grupy operacyjne. Na podstawie rozkazu Sztabu Generalnego WP z 9 listopada 1918 roku w trzech okręgach wojskowych: warszawskim, łódzkim i piotrkowskim przystąpiono do tworzenia Legii Akademickiej grupującej młodzież wyższych uczelni ${ }^{12}$.

Dnia 22 października 1918 roku zalążek odrodzonego Wojska Polskiego w postaci Polskiej Siły Zbrojnej liczył 5401 ludzi. W ciągu następnych dwóch tygodni jego stan osobowy niemal się podwoił i 2 listopada 1918 roku wynosił, oprócz personelu Ministerstwa Spraw Wojskowych i Sztabu Generalnego WP, 9232 osoby. W tej liczbie znajdowało się 342 oficerów, 135 podchorążych, 1007 podoficerów i 7748 szeregowców $^{13}$.

8 Ibidem, s. 139, 147; M. Zgórniak, Wojsko Polskie w pierwszych latach II Rzeczypospolitej (1918-1921), [w:] idem, Studia i rozprawy z dziejów XVI-XX wieku. Historia, militaria, polityka, Kraków 2009, s. 170.

9 Odrodzenie Wojska Polskiego 1918-1921 w materiałach..., s. 139, 151.

10 Ibidem, s. 140, 148; M. Zgórniak, op. cit., s. 170.

11 Odrodzenie Wojska Polskiego 1918-1921 w materiałach..., s. 145.

12 Legia Akademicka stała się bazą powstałego w grudniu 1918 roku 36. pułku piechoty. Jednostka ta, wchodząca w skład 8. Dywizji Piechoty, z powodzeniem walczyła na froncie ukraińskim i litewsko-białoruskim. Ibidem, s. 140, 161.

13 Ibidem, s. 121. 
Do początku listopada 1918 roku w szeregach organizującego się Wojska Polskiego służyli głównie oficerowie i żołnierze Polskiej Siły Zbrojnej, byłego Polskiego Korpusu Posiłkowego, byłych armii państw rozbiorowych oraz w niewielkiej liczbie byli legioniści ${ }^{14}$. W pierwszej grupie generałów, którzy zdecydowali się na współuczestnictwo w jego tworzeniu, znaleźli się Wacław Iwaszkiewicz, Kajetan Olszewski i Stanisław Szeptycki.

Powołanie 28 października 1918 roku w Krakowie Polskiej Komisji Likwidacyjnej oraz usunięcie miejscowego garnizonu austriackiego stało się sygnałem do organizowania polskich formacji zbrojnych w Galicji. Tworzono je głównie w Krakowie i miastach stanowiących siedziby garnizonów austriackich. Wstępowali do nich ochotniczo polscy oficerowie i żołnierze z demobilizowanej armii austro-wegierskiej, byli legioniści i członkowie Polskiej Organizacji Wojskowej (POW). Komendę nad nimi z ramienia PKL objął brygadier Bolesław Roja, który dekretem Rady Regencyjnej z 1 listopada 1918 roku otrzymał awans na stopień generała i nominację na dowódcę brygady w Krakowie ${ }^{15}$.

Dnia 11 listopada 1918 roku wszystkie formacje zbrojne podporządkowane PKL liczyły 8520 ludzi zgrupowanych w czternastu batalionach i ośmiu samodzielnych kompaniach ${ }^{16}$. Powstające oddziały niemal od razu kierowano na front w Galicji Wschodniej do walki przeciwko Ukraińcom. Brały też udział w rozbrajaniu wojsk austro-węgierskich na terenach kontrolowanych przez PKL, przejmowaniu od nich jednostek i garnizonów wojskowych, a także przywracaniu porządku na obszarach objętych wrzeniem rewolucyjnym $^{17}$.

Dnia 4 listopada 1918 roku Ministerstwo Spraw Wojskowych zdecydowało o podziale obszaru Galicji na dwa okręgi wojskowe: krakowski i lwowski. Odrębny okręg wojskowy utworzono na Śląsku Cieszyńskim. Jednocześnie gen. Stanisław Szeptycki objął stanowisko tymczasowego dowódcy „wszystkich sił zbrojnych na obszarach dawnej okupacji austro-węgierskiej oraz tej części Galicji, która się pod władzą polską znajduje"18.

Do organizowania polskich formacji zbrojnych przystąpiono także w okupowanej przez wojska austro-węgierskie południowej części Królestwa Polskiego. Pod koniec października 1918 roku w Lublinie powołano trzyosobowy Komitet Wojskowy. Jego członkiem był między innymi gen. Józef Dowbór-Muśnicki, były dowódca I Korpusu Polskiego. Komitet ten, pełniąc funkcję Tymczasowej Komendy Wojskowej, miał organizować polskie kadry wojskowe w Lublinie oraz kierować akcją usuwania stacjonujących na tym terenie garnizonów austro-węgierskich ${ }^{19}$.

14 Ibidem, s. 140.

15 M. Zgórniak, Załamanie się austro-węgierskiej organizacji wojskowej na ziemiach polskich w 1918 r., [w:] idem, 1914-1918. Studia i szkice z dziejów I wojny światowej, Kraków 1987, s. 255-281; Odrodzenie Wojska Polskiego 1918-1921 w materiałach..., s. 139, 155.

16 M. Zgórniak, Wojsko Polskie w pierwszych latach..., s. 170.

17 Ibidem; L. Wyszczelski, Wojsko II Rzeczypospolitej. Armia ułanów, szarej piechoty, serca w plecaku, Warszawa 2014, s. 14.

18 Dziennik Rozporządzeń Ministerstwa Spraw Wojskowych nr 3 z 4.11.1918.

19 A. Ajnenkiel, Z dziejów Tymczasowego Rządu Ludowego w Lublinie, „Kwartalnik Historyczny” 1958, nr 4, s. 1065. 
Po rozbrojeniu wojsk okupacyjnych, co nastąpiło między 1 a 5 listopada, w nocy z 6 na 7 listopada 1918 roku w oswobodzonym Lublinie ukonstytuował się Tymczasowy Rząd Ludowy Republiki Polskiej z Ignacym Daszyńskim jako premierem. Kierowanie resortem wojny w nowym rządzie powierzono płk. Edwardowi Rydzowi-Śmigłemu. Rządowi Daszyńskiego podporządkowały się miejscowe formacje POW, polskie jednostki byłej armii austro-węgierskiej, jak również kwaterujący w Lublinie batalion Polskiej Siły Zbrojnej. Rydz Śmigły natychmiast wydał odezwę skierowaną do żołnierzy POW oraz „Wszystkich Polaków, którzy w jakiejkolwiek armii pełnili służbę wojskową” do wstępowania w szeregi powstającego Wojska Polskiego ${ }^{20}$. Do 11 listopada 1918 roku do służby w oddziałach podporządkowanych rządowi ludowemu zgłosiło się 11500 osób ${ }^{21}$. Utworzono z nich około dziesięciu batalionów i kilkanaście kompanii piechoty ${ }^{22}$. Ich wartość bojowa była jednak niska. Planowano też sformowanie większych jednostek: ośmiu pułków piechoty i kilku pułków jazdy ${ }^{23}$.

\section{Pod dowództwem Józefa Piłsudskiego — scalenie polskich formacji wojskowych}

Po przybyciu do Warszawy zwolnionego z twierdzy magdeburskiej Józefa Piłsudskiego 11 listopada 1918 roku Rada Regencyjna przekazała mu zwierzchnictwo nad podległymi jej formacjami Wojska Polskiego oraz zalążkami Ministerstwa Spraw Wojskowych i Sztabu Generalnego WP. W jej ślady poszły pozostałe lokalne ośrodki władzy — PKL w Krakowie i Tymczasowy Rząd Ludowy Republiki Polskiej w Lublinie. Tym samym w drugiej dekadzie listopada 1918 roku pod dowództwem J. Piłsudskiego znajdowało się około 30 tysięcy żołnierzy. Do tej liczby należałoby jeszcze dodać 11685 ludzi wchodzących w skład oddziałów POW, operujących w strefie okupacji niemieckiej w Królestwie ${ }^{24}$. Poza komendą Piłsudskiego pozostawały organizowane w zaborze niemieckim oddziały Armii Wielkopolskiej oraz powstająca we Francji „Błękitna Armia” gen. Józefa Hallera.

Tymczasowy Naczelnik Państwa i zarazem Naczelny Wódz w pierwszym rozkazie skierowanym do żołnierzy odradzającego się Wojska Polskiego z 12 listopada 1918 roku oświadczył:

Obejmuję nad Wami komendę w chwili, gdy serce w każdym Polaku bije silniej i żywiej, gdy dzieci naszej ziemi ujrzały słońce swobody w całym jej blasku. Z Wami razem przeżywam wzruszenie tej godziny dziejowej, z Wami razem ślubuję życie i krew swoją poświęcić na rzecz dobra Ojczyzny i szczęścia jej Obywateli ${ }^{25}$.

20 E. Rydz-Śmigły, Byście o sile nie zapomnieli. Rozkazy, artykuły, mowy 1904-1936, Lwów-Warszawa 1936, s. 67; Odrodzenie Wojska Polskiego 1918-1921 w materiałach..., s. 193.

${ }^{21}$ Ksiega chwały piechoty, red. B. Prugar-Ketling, Warszawa 1937-1939, s. 189.

22 Ibidem, s. 196.

${ }^{23}$ Ksiegga jazdy polskiej, red. B. Wieniawa-Długoszowski, Warszawa 1938, s. 106-108.

${ }^{24}$ Ksiegga chwaty piechoty..., s. 189.

25 Cyt. za: Odrodzenie Wojska Polskiego 1918-1921 w materiałach..., s. 193. 
Po objęciu przez Piłsudskiego najwyższych stanowisk w państwie i w armii organizacja Wojska Polskiego nabrała tempa. Naczelnik kwestię tę traktował priorytetowo, uważał bowiem, że siła armii jest czynnikiem decydującym o realnych możliwościach państwa, a w warunkach polskich koniecznym do wywalczenia sprawiedliwych i bezpiecznych granic oraz obrony niepodległego bytu Rzeczypospolitej ${ }^{26}$.

Do szeregów Wojska Polskiego coraz liczniej zaczęli się zgłaszać ochotnicy, najczęściej byli legioniści i członkowie POW. Podjęto też reorganizację naczelnych władz wojskowych: Ministerstwa Spraw Wojskowych i Sztabu Generalnego WP. Jej podstawowym celem było wyraźne rozgraniczenie kompetencji obu tych instytucji. Na czele Ministerstwa Spraw Wojskowych, które praktycznie do marca 1919 roku odpowiadało za całokształt kierowania wojskiem, stanął płk Jan Wroczyński. Szefem Sztabu Generalnego WP, który z czasem stał się częścią Naczelnego Dowództwa WP i jego podstawowym organem planistyczno-organizacyjnym, został gen. S. Szeptycki ${ }^{27}$.

W drugiej połowie listopada 1918 roku wprowadzono nową strukturę terenowej administracji wojskowej. Utworzono pięć okręgów generalnych: Warszawa, Lublin, Kielce, Łódź, Kraków. Każdemu z nich przydzielono kilka okręgów wojskowych. Okręgi generalne i okręgi wojskowe zostały podporządkowane Ministerstwu Spraw Wojskowych. Odpowiadały za formowanie oddziałów i związków taktycznych, ich wyszkolenie oraz materiałowe wyposażenie. Przystąpiono też do organizowania powiatowych i okręgowych komend uzupełnieńn ${ }^{28}$.

Napływ nowych ochotników sprawił, że pod koniec 1918 roku stan osobowy Wojska Polskiego wynosił już około stu tysięcy żołnierzy. Do tego czasu udało się utworzyć trzydzieści dziewięć pułków piechoty, siedemnaście pułków jazdy i trzy pułki artylerii. Rozpoczęto też formowanie pierwszego związku taktycznego piechoty - ochotniczej Dywizji Litewsko-Białoruskiej. Na jego dowódcę wyznaczono gen. Wacława Iwaszkiewicza $^{29}$. Oddziały i pododdziały dywizji miały walczyć o polskie Kresy Wschodnie.

W grudniu 1918 roku zaczęło się organizować polskie lotnictwo. Pierwsze eskadry lotnicze utworzono w Warszawie, Lwowie, Krakowie, Przemyślu i Lublinie. Lotniska, samoloty, a także pozostały sprzęt oraz uzbrojenie zostały przejęte głównie po armiach niemieckiej i austro-węgierskiej. Dnia 20 grudnia utworzono Dowództwo Wojsk Lotniczych z ppłk. pil. Hipolitem Łossowskim na czele, które zostało bezpośrednio podporządkowane szefowi Sztabu Generalnego WP. Podlegały mu wszystkie formacje lotnicze oraz Wojskowa Szkoła Lotnicza. W Warszawie i Krakowie powołano też grupy lotnicze stanowiące pośredni szczebel dowodzenia w siłach powietrznych. Były w nich zgrupowane poszczególne eskadry lotnicze. Lotnictwo początkowo było wykorzystywane przede wszystkim do utrzymywania łączności między zgrupowaniami wojsk, pro-

26 Ibidem, s. 195.

27 Ibidem, s. 141, 151; M. Zgórniak, op. cit., s. 172.

28 Ibidem; Odrodzenie Wojska Polskiego 1918-1921 w materiałach..., s. 141, 188; L. Wyszczelski, op. cit., s. 21.

29 Odrodzenie Wojska Polskiego 1918-1921 w materiałach..., s. 195, 219-220. 
wadzenia rozpoznania oraz korygowania ognia artylerii. Rzadziej służyło do niszczenia samolotów czy siły żywej przeciwnika ${ }^{30}$.

Wybuch powstania wielkopolskiego 27 grudnia 1918 roku zapoczątkował formowanie Armii Wielkopolskiej, nad którą kierownictwo objęło Dowództwo Główne Sił Zbrojnych Zaboru Pruskiego. Wojskami powstańczymi w pierwszej fazie walk dowodził były kapitan armii niemieckiej Stanisław Taczak, a od 16 stycznia 1919 roku gen. J. Dobór-Muśnicki. W ciągu zaledwie dwóch miesięcy formacje wielkopolskie przeistoczyły się w regularną armię gromadzącą w swoich szeregach ponad 70 tysięcy żołnierzy ${ }^{31}$. W jej skład wchodziły między innymi trzy dywizje strzelców wielkopolskich, brygada kawalerii i trzy brygady artylerii. Kadrę dowódczą stanowili oficerowie z byłej armii niemieckiej oraz byłych formacji polskich w Rosji. Armia Wielkopolska do maja 1919 roku nie podlegała rozkazom Naczelnego Dowództwa WP, co jednak nie przeszkadzało, aby jej wydzielone jednostki już wcześniej mogły walczyć na froncie wschodnim ${ }^{32}$.

Poza krajem, we Francji formowała się Armia Polska gen. J. Hallera, nad którą pieczę sprawował Komitet Narodowy Polski z Romanem Dmowskim na czele. Napływali do niej ochotnicy - Polacy mieszkający we Francji, Włoszech, USA i Kanadzie oraz jeńcy pochodzenia polskiego $\mathrm{z}$ armii państw centralnych, wzięci do niewoli na froncie francuskim i włoskim. Generał Haller objął nad nimi dowództwo 4 października 1918 roku. Organizowanie armii trwało praktycznie przez cały 1918 rok, również po zakończeniu działań wojennych. Zajmowała się tym Misja Wojskowa Francusko-Polska. Strona francuska wzięła na siebie koszty utrzymania, wyposażenia i wyszkolenia oddziałów polskich. Na wiosnę 1919 roku, tuż przed wyjazdem do kraju, „Błękitna Armia" liczyła blisko 70 tysięcy żołnierzy. W jej składzie znajdowało się miedzy innymi: pięć dywizji strzelców i tak zwana dywizja instrukcyjna oraz siedem pułków artylerii, trzy pułki kawalerii i siedem eskadr lotniczych ${ }^{33}$. Jak na polskie warunki formacja ta była bardzo dobrze wyszkolona i wyposażona w sprzęt wojskowy. W swoim arsenale posiadała również broń, która dopiero wchodziła do użytku w siłach zbrojnych zachodnich potęg militarnych - czołgi. Zostały one zgrupowane w pierwszym pułku czołgów. Po przyjeździe do kraju jednostka ta stała się podstawą organizowania polskiej broni pancernej ${ }^{34}$.

W 1919 roku kontynuowano intensywną rozbudowę Wojska Polskiego. Był to czas dynamicznego wzrostu jego stanów osobowych, tworzenia wielkich jednostek — brygad i dywizji, ujednolicania struktur organizacyjnych pododdziałów, oddziałów i związków taktycznych. Dokonało się też scalenie w ramach sił zbrojnych wszystkich polskich formacji wojskowych, a Wojsko Polskie przekształcono w armię regularną.

30 Ibidem, s. 141, 203; L. Wyszczelski, op. cit., s. 35; Zarys dziejów wojskowości polskiej w latach 18641939, red. P. Stawecki, Warszawa 1990, s. 287.

31 M. Wrzosek, Wojny o granice Polski Odrodzonej 1918-1921, Warszawa 1992, s. 49.

32 M. Zgórniak, op. cit., s. 173-174; Z. Jagiełło, Piechota Wojska Polskiego 1918-1939, Warszawa 2005, s. $29-31$.

33 Odrodzenie Wojska Polskiego 1918-1921 w materiałach..., s. 79-83; M. Zgórniak, op. cit., s. 175-176; J. Haller, Pamiętniki, Londyn 1964, s. 371-373.

34 M. Zgórniak, op. cit., s. 176; L. Wyszczelski, Wojsko Polskie w latach 1918-1921, Warszawa 2006, s. 71. 
W połowie stycznia 1919 roku stan liczebny polskich sił zbrojnych przekraczał 110 tysięcy żołnierzy. W jego szeregach, oprócz wspomnianych legionistów i działaczy POW, służbę pełnili byli żołnierze armii państw zaborczych, żołnierze polskich korpusów tworzonych w Rosji oraz licealiści i studenci. W tym okresie zdołano już sformować ponad sto batalionów piechoty, siedemdziesiąt szwadronów jazdy, osiemdziesiąt baterii artylerii. Funkcjonowało kilka eskadr lotniczych oraz wiele jednostek technicznych, między innymi saperskich, łączności, kolejowych czy taborowych ${ }^{35}$.

W 1918 roku i pierwszych miesiącach 1919 roku formowanie Wojska Polskiego było oparte głównie na zaciągu ochotniczym. Tylko wyjątkowo decydowano się na przymusowy pobór w określonych częściach kraju. Pierwszy z nich miał miejsce w grudniu 1918 roku w Galicji Zachodniej. Objął cztery roczniki mężczyzn (1896-1899), umożliwiając wcielenie do armii niemal 37 tysięcy osób ${ }^{36}$. Kolejny pobór lokalny przeprowadzono w styczniu 1919 roku na obszarze byłego Królestwa Polskiego, powołując pod broń ponad 14 tysięcy mężczyzn urodzonych w roku $1898^{37}$.

W tym okresie brakowało kompleksowego i spójnego planu organizacyjnego armii. Wiele pododdziałów i oddziałów tworzono oddolnie, w sposób żywiołowy, bez udziału Ministerstwa Spraw Wojskowych i Sztabu Generalnego WP. Powstawały one z inicjatywy kadry dowódczej, podoficerskiej, szeregowych żołnierzy czy młodzieży akademickiej. Formacje te często nie miały jednolitej i ustabilizowanej struktury organizacyjnej. Różna i zmienna była także ich liczebność.

Natężenie walk o granice oraz rozpoczęcie wojny z Rosją Radziecką spowodowały konieczność wzmożenia wysiłku militarnego przez dalszą rozbudowę Wojska Polskiego. Zaciąg ochotniczy nie był w stanie podołać temu wyzwaniu. Dlatego na wniosek Naczelnego Wodza w marcu 1919 roku Sejm Ustawodawczy RP uchwalił przymusowy pobór sześciu roczników mężczyzn ${ }^{38}$. Przystąpiono też do realizacji planu rozwoju armii, przewidującego wystawienie między innymi dwunastu dywizji piechoty, brygady piechoty górskiej, sześciu brygad jazdy, kilkudziesięciu pododdziałów artylerii i kilkunastu eskadr lotniczych ${ }^{39}$. Latem 1919 roku plan ten zmodyfikowano, zwiększając liczbę formowanych dywizji piechoty do dwudziestu, a brygad jazdy do siedmiu ${ }^{40}$.

Jednocześnie podjęto wysiłek unifikacji struktur organizacyjnych Wojska Polskiego. We wszystkich broniach głównych, to jest w piechocie, kawalerii i artylerii, zdecydowano o powołaniu związków taktycznych. Uporządkowano też struktury wewnętrzne tych ostatnich. W skład dywizji piechoty miały teraz wchodzić dwie brygady piechoty (każda złożona $\mathrm{z}$ dwóch pułków piechoty), brygada artylerii, dywizjon jazdy dywizyjnej lub szwadron dragonów, niezbędne oddziały techniczne i pomocnicze oraz zakłady woj-

\footnotetext{
35 M. Zgórniak, op. cit., s. 172; Odrodzenie Wojska Polskiego 1918-1921 w materiałach..., s. 219.

36 P. Stawecki, Wskrzeszenie Wojska Polskiego na przełomie lat 1918 i 1919, „Studia i Materiały do Historii Wojskowości" 29, 1986, s. 223.

37 B. Woszczyński, Ministerstwo Spraw Wojskowych (1919-1921). Zarys organizacji i działalności, Warszawa 1972, s. 113.

38 Ksiega chwały piechoty..., s. 205; P. Stawecki, op. cit., s. 225.

39 Odrodzenie Wojska Polskiego 1918-1921 w materiałach..., s. 219; L. Wyszczelski, op. cit., s. 70.

40 Ibidem.
} 
skowe $^{41}$. Brygada jazdy powinna była posiadać trzy pułki kawalerii i dywizjon artylerii konnej ${ }^{42}$, a brygada artylerii - pułk artylerii polowej i dywizjon artylerii ciężkiej ${ }^{43}$.

W celu sprawnego zasilania istniejących i organizowanych jednostek rozwijano sieć komend uzupełnień. Każda z dywizji piechoty dysponowała własnym okręgiem uzupełniającym złożonym z czterech powiatowych komend uzupełnień, po jednej dla każdego pułku $^{44}$.

W 1919 roku dokonało się zjednoczenie wszystkich polskich formacji wojskowych — Wojska Polskiego, Armii Polskiej we Francji, Armii Wielkopolskiej i 4. Dywizji Strzelców gen. Lucjana Żeligowskiego. Integracja wojsk Hallera z resztą polskich sił zbrojnych przebiegała stopniowo. Rozkaz Naczelnego Dowództwa WP, podpisany przez J. Piłsudskiego, na mocy którego weszły one w skład Wojska Polskiego, został wydany już 9 czerwca 1919 roku $^{45}$. Faktycznie jednak nastąpiło to we wrześniu tego roku, po pokonaniu pewnych przeszkód natury organizacyjnej. Wówczas na bazie sześciu trzypułkowych dywizji strzeleckich Armii Hallera utworzono trzy czteropułkowe dywizje piechoty oznaczone numerami 11,12, i $13^{46}$.

Dłużej przebiegał proces scaleniowy formacji wielkopolskich. W maju 1919 roku zostały one poufnie podporządkowane Piłsudskiemu ${ }^{47}$. Następnie 20 sierpnia tego roku, po podjęciu przez Sejm Ustawodawczy RP uchwały o zjednoczeniu byłej Dzielnicy Pruskiej z Rzecząpospolitą, ukazał się dekret Naczelnego Wodza J. Piłsudskiego o podporządkowaniu sił zbrojnych w byłym zaborze pruskim Naczelnemu Dowództwu WP i Ministerstwu Spraw Wojskowych ${ }^{48}$. Ostatecznie dokonało się to dopiero w grudniu 1919 roku. Po włączeniu w skład Wojska Polskiego trzy dywizje strzelców wielkopolskich tworzyły 14., 15., i 17. DP ${ }^{49}$. Natomiast sformowaną na terenie Prus Wschodnich Dywizję Pomorską przemianowano na 16. $\mathrm{DP}^{50}$.

W czerwcu 1919 roku powróciła do kraju kwaterująca w rejonie Odessy 4. Dywizja Strzelców gen. Żeligowskiego. Kadry jej posłużyły do utworzenia 10. DP ${ }^{51}$. Tym samym proces jednoczenia wszystkich polskich formacji zbrojnych w ramach jednolitego Wojska Polskiego został praktycznie zakończony. Z tej okazji 10 października 1919 roku w Krakowie odbyła się specjalna uroczystość ${ }^{52}$.

Wejście w skład Wojska Polskiego nowych komponentów, zwłaszcza „hallerczyków” i oddziałów wielkopolskich, znacząco go wzmocniło pod względem zarówno liczebnym,

${ }^{41}$ L. Wyszczelski, Wojsko II Rzeczypospolitej..., s. 31; M. Zgórniak, op. cit., s. 174-175.

${ }^{42}$ L. Wyszczelski, op. cit., s. 32.

43 L. Wyszczelski, Wojsko Polskie w latach 1918-1921..., s. 72.

44 Ksiega chwaly piechoty..., s. 205.

45 Odrodzenie Wojska Polskiego 1918-1921 w materiałach..., s. 220, 244.

46 W styczniu 1920 roku na bazie oddziałów Armii Hallera sformowano jeszcze 18. Dywizję piechoty.

Z. Jagiełło, op. cit., s. 28-29.

47 Ibidem, s. 29.

48 Odrodzenie Wojska Polskiego 1918-1921 w materiałach..., s. 220, 255.

49 Ibidem, s. 220.

50 Z. Jagiełło, op. cit., s. 31.

51 L. Wyszczelski, op. cit., s. 72.

52 A. Przybylski, Wojna polska 1918-1921, Warszawa 1930, s. 101. 
jak też technicznym. Przy pomocy posiadanego przez nie sprzętu rozwijano lub tworzono nowe rodzaje broni, wojsk i służb, na przykład lotnictwo lub broń pancerną.

W połowie sierpnia 1919 roku stan osobowy Wojkka Polskiego wynosił ponad 550 tysięcy żołnierzy, z których niemal połowa służyła w jednostkach frontowych ${ }^{53}$. W grudniu tego roku pod bronią znajdowało się już 600 tysięcy żołnierzy, w tym ponad 20 tysięcy oficerów $^{54}$. Wojsko Polskie dysponowało wówczas sześcioma grupami operacyjnymi, grupą artylerii płk. Ładzińskiego, dwudziestoma jeden dywizjami piechoty, siedmioma brygadami jazdy, czterema pułkami strzelców konnych oraz wieloma jednostkami pozostałych broni i służb ${ }^{55}$. Oprócz oddziałów regularnych tworzono formacje zapasowe i rezerwowe ${ }^{56}$.

Utrzymywanie tak licznej armii wymagało ogromnych nakładów finansowych. W latach 1918-1920 siły zbrojne pochłaniały 55\% ogólnych wydatków państwa ${ }^{57}$. W 1919 roku koszty funkcjonowania Wojska Polskiego szacowano na $877 \mathrm{mln}$ franków szwajcarskich. Podobną kwotę wydatkowano w 1920 roku $^{58}$. Nowo powstałe i dodatkowo zdewastowane przez wojnę państwo polskie nie było w stanie samo pokryć tych sum, dlatego musiało posiłkować się kredytami zagranicznymi. Zaciągano je w różnych państwach, głównie we Francji, Wielkiej Brytanii, Stanach Zjednoczonych i Włoszech. Kupowano za nie broń i sprzęt wojskowy, których nie mógł samodzielnie wytworzyć raczkujący dopiero rodzimy przemysł zbrojeniowy ${ }^{59}$. Na koniec 1921 roku zadłużenie Polski z tytułu tych dostaw przekraczało 272 mln dolarów ${ }^{60}$. Inną konsekwencją sięgania po zagraniczną broń było to, że żołnierze WP posługiwali się różnorodnym sprzętem, co powodowało określone komplikacje. Pierwsze próby jego unifikacji podjęto dopiero wiosną 1920 roku. Dostawy uzbrojenia z zagranicy, w większości pochodzącego z demobilu, choć nieodzowne, tylko częściowo poprawiały niski na ogół stan wyposażenia technicznego Wojska Polskiego ${ }^{61}$.

Do końca 1919 roku powołano trzy nowe okręgi generalne: we Lwowie, Przemyślu i Poznaniu. Utworzono również inspektoraty poszczególnych broni, które zostały bezpośrednio podporządkowane Naczelnemu Wodzowi ${ }^{62}$.

\section{Walki na Wschodzie i dalsza rozbudowa Wojska Polskiego}

W związku z planowanymi przez J. Piłsudskiego operacjami zaczepnymi na froncie wschodnim w pierwszych miesiącach 1920 roku szybko zwiększano stany osobowe sił

\footnotetext{
53 L. Wyszczelski, op. cit., s. 77.

54 Ibidem; A. Przybylski, op. cit., s. 101.

55 Odrodzenie Wojska Polskiego 1918-1921 w materiałach..., s. 220.

56 L. Wyszczelski, op. cit., s. 72, 82, 84; Z. Jagiełło, op. cit., s. 31-32.

57 K. Krzyżanowski, Wydatki wojskowe Polski w latach 1918-1939, Warszawa 1976, s. 31.

58 Ibidem, s. 33.

59 Ibidem, s. 46-55.

60 M. Zgórniak, op. cit., s. 177.

61 Szerzej zob. Z. Jagiełło, op. cit., s. 173-189.

62 M. Zgórniak, op. cit., s. 176.
} 
zbrojnych. W styczniu i lutym pod broń powołano dwa nowe roczniki poborowych, co pozwoliło podnieść liczebność Wojska Polskiego o ponad 155 tysięcy żołnierzy ${ }^{63}$. W przeddzień wyprawy na Kijów grupowało ono w swoich szeregach ponad 750 tysięcy ludzi ${ }^{64}$. Uzupełniono też uzbrojenie i wyposażenie w jednostkach liniowych.

Przeprowadzono reorganizację Sztabu Generalnego WP, powołano Sztab Ścisły Naczelnego Wodza ${ }^{65}$, a w miejsce frontów wschodnich powołano pięć armii. Każda z nich składała się z trzech lub czterech dywizji piechoty oraz kilku pułków jazdy. Dowództwa armii podlegały bezpośrednio Naczelnemu Wodzowi. W istniejących i nowo formowanych jednostkach uzupełniono stany osobowe ${ }^{66}$.

W kwietniu 1920 roku podjęto też decyzję o ujednoliceniu broni w ramach poszczególnych związków taktycznych i okręgów generalnych. I tak jedenaście dywizji piechoty wyposażono w broń produkcji francuskiej, siedem - w niemiecką, a dalsze trzy - w austro-węgierską. Kawaleria miała wyłącznie broń produkcji niemieckiej i austro-węgierskiej ${ }^{67}$.

Załamanie się polskiej ofensywy na Ukrainie w maju 1920 roku oraz marsz Armii Czerwonej na Warszawę były dla Polski sytuacją krytyczną. W obliczu groźby utraty niepodległości zdecydowano się na pełną mobilizację sił i środków. Aby zrównoważyć duże straty, jakie poniosła armia polska podczas odwrotu, wcielono do niej nowe zastępy poborowych ${ }^{68}$. Przystąpiono również do formowania Armii Ochotniczej ${ }^{69}$. Nowym ministrem Spraw Wojskowych został gen. Kazimierz Sosnkowski, a szefem Sztabu Generalnego WP gen. T. Jordan-Rozwadowski ${ }^{70}$.

W 1920 roku nastąpiło rozstrzygnięcie w wojnie z Rosją Radziecką. W decydujących, niezwykle krwawych zmaganiach, jakie toczyły się latem i wczesną jesienią, Armia Czerwona została pokonana i zmuszona do wycofania się z ziem wschodnich Rzeczypospolitej. Wojsko Polskie obroniło nie tylko niepodległość Polski, lecz także zapobiegło rozlaniu się rewolucji bolszewickiej na całą Europę. Było to możliwe dzięki olbrzymiemu wysiłkowi militarnemu Rzeczypospolitej, który osiągnął wówczas swoje apogeum.

Najwyższych stanów osobowych Wojsko Polskie dorobiło się tuż po zakończeniu bitwy na przedpolach Warszawy 1 września 1920 roku. Grupowało ono wówczas 943976 żołnierzy, w tym 26478 oficerów oraz 917498 podoficerów i szeregowców ${ }^{71}$. Z tej licz-

63 M.J. Szczepkowski, Zarys organizacji Wojska Polskiego w latach 1918-1920, „Wojskowy Przegląd Historyczny" 1990, nr 3-4, s. 18.

${ }^{64} \mathrm{Na}$ front wysłano 258 batalionów piechoty, 108 szwadronów jazdy i 229 baterii artylerii. Ibidem, s. 21 , tabela 2 .

${ }^{65}$ M. Zgórniak, op. cit., s. 178.

66 A. Przybylski, op. cit., s. 182.

67 L. Wyszczelski, op. cit., s. 81; M. Zgórniak, op. cit., s. 177-178.

68 W okresie od 1 lipca do 20 sierpnia 1920 roku szeregi wojska zasiliło ponad 164 tys. osób. W. Pobóg-Malinowski, Najnowsza historia polityczna Polski, t. 2. 1914-1939, Londyn 1967, s. 453.

69 Jej organizacją zajął się utworzony 7 lipca 1920 roku Generalny Inspektorat Armii Ochotniczej z gen. Józefem Hallerem na czele. Wprawdzie Armii Ochotniczej nie sformowano, ale przeprowadzony zaciąg powiększył stan Wojska Polskiego o około 80 tys. ludzi. Ibidem, s. 452; Księga chwały piechoty..., s. 222.

70 M. Zgórniak, op. cit., s. 179.

${ }^{71}$ L. Wyszczelski, op. cit., s. 86-87. 
by w obszarze frontowym znajdowało się 348284 żołnierzy, a w głębi kraju $595692^{72}$. W tym czasie w jego składzie znajdowało się między innymi: dwadzieścia dwie dywizje piechoty, trzy samodzielne brygady piechoty, dziesięć brygad jazdy, dwadzieścia brygad artylerii polowej, brygada artylerii górskiej, dziewiętnaście eskadr lotniczych. Uzbrojenie Wojska Polskiego pozostawiało wiele do życzenia i składało się z około 430 tysięcy karabinów ręcznych, 6,5 tysięcy karabinów maszynowych, 2000 dział, stu dwudziestu czołgów, czterdziestu trzech samochodów pancernych, dwudziestu sześciu pociągów pancernych i około dwustu samolotów ${ }^{73}$.

Warto dodać, że w całym analizowanym okresie, czyli w latach 1918-1921, przez szeregi Wojska Polskiego przeszło około 1350000 żołnierzy, z których około 250000 poległo $^{74}$. Była to wielka danina krwi, którą przyszło Polakom zapłacić za wskrzeszenie wolnej ojczyzny.

\section{Demobilizacja}

Zakończenie wojny z Rosją Radziecką stworzyło warunki do przeprowadzenia demobilizacji armii i jej przejścia na organizacje pokojową ${ }^{75}$. Według informacji przekazanych przez ministra spraw wojskowych posłom na posiedzeniu Sejmu RP 8 marca 1921 roku pokojowy etat Wojska Polskiego przewidywał 17 tysięcy oficerów, 275 tysięcy podoficerów i szeregowych oraz 80 tysięcy koni ${ }^{76}$. Miało ono dysponować między innymi trzydziestoma dywizjami piechoty, dziewięcioma brygadami kawalerii, trzydziestoma pułkami artylerii polowej, dziesięcioma pułkami artylerii ciężkiej, pułkiem artylerii górskiej, dziesięcioma pułkami saperów, trzema pułkami łączności i trzema pułkami lotniczymi ${ }^{77}$.

Kraj podzielono na dziesięć okręgów korpusów, których dowództwa rozlokowano w Warszawie (OK I), Lublinie (OK II), Wilnie (OK III), Łodzi (OK IV), Krakowie (OK V), Lwowie (OK VI), Poznaniu (OK VII), Toruniu (OK VIII), Brześciu (OK IX) i Przemyślu (OK X). Miały one odpowiadać za mobilizację jednostek znajdujących się na ich terenie na podstawie planów mobilizacyjnych ${ }^{78}$.

Utworzono też pięć inspektoratów armii, z których każdy obejmował dwa okręgi korpusów. Na siedziby inspektoratów armii wyznaczono: Wilno (IA nr 1), Warszawę (IA nr 2), Toruń (IA nr 3), Kraków (IA nr 4), Lwów (IA nr 7). Po wybuchu wojny inspekto-

72 Ibidem, s. 87.

${ }^{73}$ M. Cieplewicz, Wojsko Polskie w latach 1921-1926. Organizacja, wyposażenie, wyszkolenie, Wrocław 1998, s. 10; L. Wyszczelski, Wojsko II Rzeczypospolitej..., s. 33, 35.

${ }^{74}$ M. Wrzosek, op. cit., s. 83.

75 Ogółem w okresie od września 1920 roku do końca 1921 roku zdemobilizowano w Wojsku Polskim 795987 żołnierzy, w tym ponad 8500 oficerów. Stanowiło to prawie $80 \%$ stanu sił zbrojnych w momencie podpisywania traktatu ryskiego. Z. Jagiełł, op. cit., s. 37.

${ }^{76}$ M. Zgórniak, op. cit., s. 182.

77 B. Wyszyński, op. cit., s. 228.

78 Szerzej zob: L. Wyszczelski, Od demobilizacji do zamachu majowego. Wojsko Polskie w latach 19211926, Warszawa 2007, s. 119-127. 
rzy mieli dowodzić pięcioma armiami polowymi ${ }^{79}$. Ponadto w Wilnie, Warszawie i we Lwowie powołano trzy inspektoraty jazdy. Inspektorzy jazdy w razie wybuchu wojny mieli stanąć na czele dywizji kawalerii ${ }^{80}$. W maju 1921 roku rozformowano Naczelne Dowództwo Wojska Polskiego ${ }^{81}$.

\section{Podsumowanie}

W podsumowaniu należy stwierdzić, że powstające od jesieni 1918 roku w niezwykle trudnych i złożonych warunkach Wojsko Polskie stanęło na wysokości zadania. W krwawych zmaganiach wywalczyło dla Rzeczypospolitej granice na wschodzie, obroniło świeżo uzyskaną państwowość oraz uchroniło Europę przed realnym niebezpieczeństwem bolszewizacji. W ciągu dwóch kolejnych dekad wojsko to stało się gwarantem niepodległości i integralności terytorialnej Polski. Było też znaczącą siłą militarną w Europie Środkowo-Wschodniej oraz ważnym czynnikiem kształtującym międzynarodową pozycję Rzeczypospolitej w okresie międzywojennym.

\section{Bibliografia}

Ajnenkiel A., Z dziejów Tymczasowego Rządu Ludowego w Lublinie, „Kwartalnik Historyczny” 1958, nr 4.

Cieplewicz M., Wojsko Polskie w latach 1921-1926. Organizacja, wyposażenie, wyszkolenie, Ossolineum, Wrocław 1998.

Dziennik Rozporządzeń Ministra Spraw Wojskowych nr 3 z 4.11.1918.

Haller J., Pamiętniki, Katolicki Ośrodek Wydawniczy „Veritas”, Londyn 1964.

Jagiełło Z., Piechota Wojska Polskiego 1918-1939, Bellona, Warszawa 2005.

Krzyżanowski K., Wydatki wojskowe Polski w latach 1918-1939, PWN, Warszawa 1976.

Księga chwaly piechoty, red. B. Prugar-Ketling, Departament Piechoty Ministerstwa Spraw Wojskowych, Warszawa 1937-1939.

Księga jazdy polskiej, red. B. Wieniawa-Długoszowski, Instytut Wydawniczy „Biblioteka Polska”, Warszawa 1938.

Odrodzenie Wojska Polskiego 1918-1921 w materiałach Centralnego Archiwum Wojskowego, Wydawnictwo ZP, Warszawa 2008.

Pobóg-Malinowski W., Najnowsza historia polityczna Polski, t. 2. 1914-1939, Wydawnictwo B. Świderski, Londyn 1967.

Przybylski A., Wojna polska 1918-1921, Wojskowy Instytut Naukowo-Wydawniczy, Warszawa 1930.

Rydz-Śmigły E., Byście o sile nie zapomnieli. Rozkazy, artykuły, mowy 1904-1936, Książnica-Atlas, Lwów-Warszawa 1936.

Stawecki P., Wskrzeszenie Wojska Polskiego na przełomie lat 1918 i 1919, „Studia i Materiały do Historii Wojskowości” 29, 1986.

Szczepkowski M.J., Zarys organizacji Wojska Polskiego w latach 1918-1920, „Wojskowy Przegląd Historyczny" 1990 , nr 3-4.

\footnotetext{
79 Ibidem, s. $80-87$.

80 Ibidem, s. 87-88.

81 Nastąpiło to na podstawie dekretu J. Piłsudskiego z 3 kwietnia 1921 roku. Ibidem, s. 80.
} 
Woszczyński B., Ministerstwo Spraw Wojskowych (1919-1921). Zarys organizacji i działalności, WIH, Warszawa 1972.

Wrzosek M., Wojny o granice Polski Odrodzonej 1918-1921, Wiedza Powszechna, Warszawa 1992.

Wyszczelski L., Od demobilizacji do zamachu majowego. Wojsko Polskie w latach 1921-1926, Wydawnictwo

Neriton, Warszawa 2007.

Wyszczelski L., Wojsko II Rzeczypospolitej. Armia ułanów, szarej piechoty i serca w plecaku, Bellona, Warszawa 2014.

Wyszczelski L., Wojsko Polskie w latach 1918-1921, Wydawnictwo Neriton, Warszawa 2006.

Zarys dziejów wojskowości polskiej w latach 1864-1939, red. P. Stawecki, MON, Warszawa 1990.

Zgórniak M., Wojsko Polskie w pierwszych latach II Rzeczypospolitej (1918-1921), [w:] idem, Studia i rozprawy z dziejów XVI-XX wieku. Historia, militaria, polityka, Księgarnia Akademicka, Kraków 2009.

Zgórniak M., Załamanie się austro-wegierskiej organizacji wojskowej na ziemiach polskich w 1918 r., [w:] idem, 1914-1918. Studia i szkice z dziejów I wojny światowej, Wydawnictwo Literackie, Kraków 1987.

\section{The revival of the Polish Army 1918-1921}

Keywords: Polish Army, independence, formation, front, recruitment, integration, service, warfare

Summary

The Polish Army began to form before the resurrection of the Polish state. After Józef Piłsudski took over the highest positions in the state and army, the pace of organization in the Polish Army quickened. The Chief of State treated this issue as a priority. He believed the strength of the army to be a decisive factor in the real possibilities of the state, and in Polish conditions necessary to win the righteous and safe borders and defend the independent existence of the Republic of Poland. The inflow of new volunteers meant that at the end of 1918 the number was already around 100,000 soldiers. Until then, 39 infantry regiments, 17 regiments and 3 artillery regiments were successfully formed. In 1919, the intensive development of the Polish Army continued. It was a time of dynamic development of its strength, creation of great units - brigades and divisions, unification of organizational structures of sub-units, units and tactical units. There was also a consolidation of all Polish military formations within the armed forces, and the Polish Army was transformed into a regular army. The highest strength of the Polish Army was reached just after the end of the battle in the outskirts of Warsaw, on 1 September 1920, as it numbered 943,976 soldiers. At that time, its composition included, among others: 22 infantry divisions, 3 independent infantry brigades, 9 motorized brigades, 20 field artillery brigades, a mountain artillery brigade, 20 air squadrons. 